\title{
Northern Norwegian Degree Questions and the Syntax of Measurement
}

\author{
Peter Svenonius and Christopher Kennedy \\ University of Troms $\varnothing$ and University of Chicago
}

DRAFT: November 2, 2005

\begin{abstract}
Norwegian dialects, including Northern Norwegian (NN), make use of degree questions with no overt degree operator (Null Degree Questions, NDQs). These questions have a gradable adjective in situ and subject-verb inversion, for example Er du gammel?, literally 'Are you old?', has the interpretation "How old are you?" In this paper we provide a detailed syntactic and semantic analysis for NDQs in NN which provides new insight into the decompositional semantics of adjectives more generally. We show how our analysis fits in with current research into the syntax and semantics of measure phrases and comparatives.
\end{abstract}

\section{Degree questions in Northern Norwegian}

\subsection{Various Scandinavian degree question operators}

Scandinavian languages generally form degree questions in the same way as English does, where a question word (English how) pied-pipes a degree adjective.

a. How old are you?

b. How far is it to Alaska?

Here we illustrate with Icelandic in (2) and with Norwegian in (3); we gloss Icelandic hversu as 'how much' because it is only used as a degree operator, lacking the manner adverbial use of English how, and we gloss Norwegian kor as 'where' because it has a locative meaning in the absence of an adjective (as in Kor er han? 'Where is he?').

a. Hversu gammall ertu?

how.much old are.you

'How old are you'?

b. Hversu langt er til Pingvalla?

how.much far is to Thingvellir

'How far is it to Thingvellir?' (Icelandic) 
a. Kor gammel er du?

where old are you

'How old are you?'

b. Kor langt er det til Nordkapp?

where far is it to North.cape

'How far it is to the North Cape?' (Norwegian)

In addition to the above strategy, Icelandic can front a different question word, corresponding approximately to English what, and leave the adjective in situ.
a. Hvað ertu gammall?
what are.you old
'How old are you?'
b. Hvað er langt til Pingvalla?
what is far to Thingvellir
'How far is it to Thingvellir?' (Icelandic)

Norwegian dialects in the northwest and north of Norway (stretching from Nordmøre and Trøndelag northwards, Endresen 1985) also have an alternative to (3), which like the Icelandic option has the adjective in situ. Unlike the Icelandic construction, there no overt question word. Instead, as we will demonstrate in section 2 , there is a phonologically null counterpart to Icelandic $h v a \gamma$ :
a. Er du gammel?
are you old
'How old are you?'
b. Er det langt til Nordkapp?
is it far to north.cape
'How far is it to the North Cape?' (Northern Norwegian)

The questions in (5) are string identical to yes-no questions in NN, but they are intonationally distinct (see the next subsection). They are unambiguously interpreted as degree questions by speakers of these dialects, though speakers in the southeast and south of Norway do not recognize them as such and often find them confusing or mistake them for yes-no questions (as noted by Endresen 1985). In this section, we show that the degree interpretation is not a pragmatic reinterpretation of a yes-no question, and point out some restrictions on the construction.

We draw our data from Northern Norway, in particular around Troms $\varnothing$ and Narvik; henceforth we will refer to these dialects as NN. ${ }^{1}$ There is some small variation in the way the construction is used from one dialect to the next (cf. Bull 1987 for some examples), but to the best of our knowledge our remarks hold for dialects as far south as Nordmøre, and for the Icelandic construction, apart from the fact that the Icelandic counterpart of the operator has phonological content.

\footnotetext{
${ }^{1}$ Except where noted, all examples in this paper are NN, in a standardized orthography, lightly modified to reflect salient dialectal features. In some cases we have based examples on Endresen 1985 or Midtgård 1995 but standardized the orthography.
} 
We will suggest, then, that degree questions can vary at least along two parameters: whether the degree question operator pied-pipes the adjective with which it is associated, and whether the degree question operator is pronounced. We have found in Scandinavian languages three of the four possible combinations of these two points of variation. It is an open question whether a language could also have a null degree operator which pied-piped an adjective, yielding degree questions roughly like "Old are you?"2

\subsection{Syntax/Semantics versus Pragmatics}

Previous work on what we will call null operator degree questions, or NDQs, in Norwegian dialects has concurred that they cannot be analyzed in terms of a pragmatic interpretation of a formal yes-no question (Endresen 1985, Bull 1987, Midtgård 1995), and we agree with this assessment.

First, as noted above, the construction is systematically intonationally distinct from a yes-no question. Yes-no questions tend to have their prosodic peak on the most deeply embedded part of the sentence, which may be a predicative adjective, for example cold in Are you cold? NDQs never have an intonational peak on the adjective, but typically have the stress further to the left (Endresen 1985). Here we use underlining to represent intonation peak.
a. Vil du ha mange?
will you have many
'Do you want many?'
b. Vil du ha mange?
will you have many
'How many would you like?'

a. Har du vært her lenge?
have you been here long
'Have you been here long?'

b. Har du vært her lenge?

have you been here long

'How long have you been here?'

As Endresen notes, the yes-no questions above (the first member of each pair) may pragmatically elicit more informative responses than a simple yes or no, depending on context. But NN speakers interpret the NDQs (the second member of each pair) as unambiguously asking for degrees. This

\footnotetext{
${ }^{2}$ In fact, such a structure is attested in Spanish in a related construction: the comparative clause of 'comparative subdeletion' structures (see Rivero 1981, Kennedy 2002):

(i) a. La mesa es más large que ancha es la puerta. the table is more long than wide is the door 'The table is longer than the door is wide.'

b. *La mesa es más large que la puerta es ancha. the table is more long than the door is wide

It is well established that comparative clause is an $\bar{A}$-movement structure, so the existence of comparatives like (i) suggests that degree questions with the same form should indeed be possible.
} 
leads to a sharp difference of intuition with southern speakers (and English speakers, for the translations). Unless southern speakers are claimed to have a different pragmatics, this suggests that the difference is grammatical, not pragmatic.

A second argument that the construction is not simply pragmatic comes from the difference between the presuppositions of degree questions and yes/no questions involving adjectival predications. A yes/no question is based on the semantics of the 'positive' (morphologically unmarked) form, which involves reference to a contextual standard of comparison: Is he old? asks whether an object's age is greater than the prevailing standard of age (for things like $X$ ) or not, and crucially presupposes that the answer to that question is not part of the common ground. In contrast, a degree question asks for the degree to which an object possesses some property: How old is $X$ asks for an object's age, and presupposes that this value is unknown, but it is completely indifferent as to whether $X$ is old or not. The prediction is that in a context in which it is part of the common ground that $X$ is old, only a degree question will be felicitous. This is illustrated by the English translations in the discourse in (8); the felicity of the NN question in (8b) shows that is must have the semantics of a degree question.
A: Læreren min er skikkelig gammel. the.teacher my is properly old 'My teacher is really old.'
B: Er han gammel?
is he old
'How old is he?'
'??Is he old?'

A third indication that the degree interpretation is not simply pragmatic is that various degree modifiers can be used in NDQs which are infelicitous in yes-no questions, for example sånn cirka, 'approximately,' as pointed out by Midtgård (1995).
a. Er den tung, sånn cirka? is it heavy such approximately 'How heavy is it, approximately?'
b. *Er den tung, sånn cirka? is it heavy such approximately (*'Is it heavy, approximately?')

We conclude that the NDQ is semantically a degree question, not a yes-no question.

\title{
1.3 The Salient Measure Restriction
}

As noted by Midtgård (1995), NDQs are not possible with all gradable adjectives.

\author{
a. Er han ung? \\ is he young \\ 'Is he young?' (NOT: 'How young is he?')
}




\section{b. Er ho flink? \\ is she talented \\ 'Is she talented?' (NOT: 'How talented is she?')}

For such adjectives, NN uses the overt degree question operator kor (kor is the Nynorsk spelling, corresponding to hvor in Bokmål; the Northern pronunciation is /ku:r/ or /ko:r/).
a. Kor ung er han? where young is he
'How young is he?'
b. Kor flink er ho? where talented is she 'How talented is she?'

The general pattern is that NDQs are possible with adjectives for which there is a salient measurement system; measurement systems are typically only used with the 'positive' member of antonymic adjective pairs, e.g. old not young, long not short, deep not shallow. Other gradable adjectives simply lack a salient measurement system, e.g. talented, beautiful, tired, hungry, etc. are gradable in that one can be very talented or more beautiful and so on, but not associated with a salient measurement system.

In the table in (12), only the adjectives in the leftmost column support NDQs. ${ }^{3}$

\begin{tabular}{ll|l|l}
\multicolumn{3}{c}{ Gradable } & NOt Gradable \\
Measure & \multicolumn{1}{c}{ No MEASURE } & \\
Positive & Negative & & \\
\hline long & short & beautiful & atomic \\
deep & shallow & intelligent & wooden \\
far & near & friendly & binary \\
old & young & tired & quadrilateral \\
expensive & cheap & happy & human \\
heavy & light & anxious & Norwegian
\end{tabular}

When a scale is referred to, it is usually the positive values of antonymic pairs which are used; thus, in degree questions where what is at issue is the place on a scale, the positive value is used; the questions in (13) can be posed neutrally to elicit information about the length of a fjord or the intelligence of moles, but the questions in (14) presuppose that Sognefjord is relatively short and that moles are relatively stupid.
a. How long is Sognefjord?
b. How intelligent are moles?
a. How short is Sognefjord?
b. How stupid are moles?

\footnotetext{
${ }^{3}$ The arrangement of the table does not reflect the fact that gradable adjectives not associated with salient measurement scales can often be arranged into antonymic pairs, e.g. beautiful-ugly, intelligent-stupid, etc.
} 
The restriction of NDQs to positive adjective associated with salient measure scales is also true of Icelandic degree questions with hvað 'what'; otherwise hversu 'how much' must be used.
a. Hvað ertu stór?
what are.you big
'How tall are you?'

b. Hversu stór ertu?

how.much big are.you

'How tall are you?'

a. Hvað er bókin dýr?

what is the.book expensive

'How expensive is the book?'

b. Hversu dýr er bókin?

how.much expensive is the.book

'How expensive is the book?'

a. *Hvað er hann dugarlegur?

what is he clever

b. Hversu dugarlegur er hann?

how.much clever is he

'How clever is he?'

(18)

a. *Hvað er hann hávær?

what is he loud

b. Hversu hávær er hann?

how.much loud is he

'How loud is he?'

There is a strong (though not perfect) correlation between the possibility of overt measure phrases and the possibility of NDQs (or Icelandic degree questions with $h v a \partial$ ). For example, overt measure phrases are illustrated below with the adjectives lang 'long,' tung 'heavy,' h $\phi j$ 'tall,' gammel 'old,' and $d y r$ 'expensive.'
a. en $100 \mathrm{~m} \quad$ lang fjord
a 100.meter long fjord
'a 100 meter long fjord'
b. en 100 kilo tung sekk
a 100 kilo heavy bag
'a 100 kilo bag'
c. en $160 \mathrm{~cm}$ høj mann
a $160 \mathrm{~cm}$ tall man
'a $160 \mathrm{~cm}$ tall man'
d. et 100 år gammelt hus
a 100 year old house
'a 100 year old house' 


\section{e. det 5 millioner kroner dyre huset \\ the 5 millions crowns expensive house \\ 'the five million kroner house'}

Note that an adjective can generally be used with a measure even if the thing being measured does not achieve the minimal standard implied by the adjective in the absence of a measure phrase: a hundred meter long fjord is not a long fjord, and a 160 centimeter tall man is not a tall man.

No such measure phrases are possible with the negative adjectives kort 'short,' lett 'light,' ny 'new,' etc.
a. *en $100 \mathrm{~m} \quad$ kort fjord
a 100.meter short fjord
b. *en $100 \mathrm{~g}$ lett sekk
a 100.gram light bag
c. *en $160 \mathrm{~cm}$ kort mann
a $160 \mathrm{~cm}$ short man

Nor are measure phrases possible with adjectives that are not associated with a measure scale.
a. *to søvnløse dager trøtt
two sleepless days tired
b. *syttifem bekymringer engstelig seventy-five worries anxious

These facts lead to the empirical generalization stated in (22).

\section{The Salient Measure Restriction}

Only gradable predicates that are associated with a measurement system give rise to NDQs

Midtgård (1995) presents the minimal pair in (23)-(24); the predicate vanskelig 'difficult' is not associated with a salient scale, and cannot support a NDQ, as indicated in (23a); the overt degree question operator must be used as seen in (23b).
a. Er det vanskelig å komme inn på den skolen?
is is difficult to come in on that school
'Is it difficult to get into that school?' (NOT: 'How difficult ...')
b. Kor vanskelig er det å komme inn på den skolen?
where difficult is it to come in on that school
'How difficult is it to get into that school?'

If the question is formed over grade point averages, which provide a salient scale, as in (24a), then the NDQ reading is possible (again, with the characteristic intonation, here stress on $m a ̊$ ), and equivalent to the question with the overt question operator in (23b).

a. Må man ha mye i snitt for å komme inn på den skolen? must one have much in average for to come in on that school 
'Does one have to have a high average to get into that school?' OR 'How high an average does one have to have to get into that school?'

b. Kor mye må man ha i snitt for å komme inn på den skolen?

how much must one have in average for to come in on that school

'How high an average does one have to have to get into that school?'

The pattern suggests that the restriction to a salient scale has a syntactic dimension: knowledge that grade-point averages are what is at stake does not make (23a) felicitous as a NDQ; gradepoint averages are not a direct measure of difficulty. They do, however, directly quantify 'how high an average' (literally "where much in average"), which licenses the NDQ reading of (24a). A word like mange 'many' always licenses a NDQ, and mye (roughly, 'much') does so whenever the substance referred to is associated with a salient countable unit of measure.
a. Vil du ha mange poteter?
will you have many potatoes
'How many potatoes do you want?'
b. Skal du låne mye penger?
shall you borrow much money
'How much money do you intend to borrow?'

The salience of the measurement system associated with a particular adjective can be affected by context and world knowledge, however. For example, when speakers are presented with the context of a game of Limbo, in which the objective is to walk under a bar held at successively lower heights, they accept (26a) as a degree question (with the right intonation, i.e. stress on gikk), and (26b) with a measure phrase.
a. Gikk du lavt?
went you low
'How low did you go?'
b. Eg gikk førti cm lavt.
I went forty cm low
'I went forty centimeters low'

Similarly, when speakers are presented with a context in which clipboard-wielding intelligence researchers are discussing an experimental subject, they are willing to accept (27a) as a degree question, and (27b) with a measure phrase.
a. Var han intelligent?
was he intelligent
'How intelligent was he?' (i.e. how many intelligence points)
b. Ho var ti poeng mer intelligent enn han.
she was ten points more intelligent than he
'She was ten points more intelligent than he was' 
Such examples are regarded as creative and/or marginal. As a final remark in this subsection, we note that the match between overt measure phrases and NDQs is not perfect. For example, NDQs are perfectly good when asking the cost of something, but overt measure phrases are not consistently good with $d y r$ 'expensive' (cf. English a forty-dollar (*expensive) watch). We believe that such mismatches have to do with idiosyncracies in the system of overt measure phrases, and concentrate in this paper on detailing the NDQ, though we return briefly to the matter below.

\subsection{Comparatives}

Comparatives of adjectives permit measure phrases, if the scale is saliently associated with a measurement, regardless of whether the adjective is the positive or negative member of the antonymic pair. For example, though $d y r$ 'expensive' but not billig 'cheap' allows a measure phrase, both the comparative dyrere and the comparative billigere do.
a. Tunfisk er 100 kroner dyrere/billigere enn den var før. tuna is 100 crowns expensiver/cheaper than it was before 'Tuna is 100 kroner more expensive/cheaper than it used to be'
b. Han Julian er 8 måneder eldre/yngre enn han Sam. he Julian is 8 months older/younger than he Sam 'Julian is 8 months older/younger than Sam'

Similarly, comparatives license NDQs, in NN (the following strings also have yes-no question interpretations, with a different intonation, as usual).
a. Er den mye dyrere/billigere enn den var før?
is it much expensiver/cheaper than it was before
'How much more expensive/cheaper is it than it used to be?'
b. Er han mye eldre/yngre enn deg?
is he much older/younger than you?
'How much older/younger is he than you?'

Neither NDQs nor measure phrases are possible with comparatives based on adjectives not associated with a salient measurement system.
a. $\quad$ Eg er (*fem timer) trøttere enn deg. I amfive hours tireder than you 'I am (*five hours) more tired than you are'
b. Er han trøttere en deg?
is he tireder than you
'Is he more tired than you?' (NOT: 'How much more tired is he than you?')

With these basic empirical facts in place, we can detail our analysis. 


\section{A null degree operator}

The existence in Icelandic of parallel constructions with an overt operator hvað lends immediate plausibility to the postulation of a null operator in NN NDQs. For the basic syntax, we assume something like (31a) for NN; cf. (31b) for Icelandic, identical except for the overtness of the operator.

$$
\begin{aligned}
& \text { a. [CP } \mathrm{Op}_{1} \mathrm{er}_{2} \text { [IP } \mathrm{du}_{3} t_{2} \text { [VP } t_{2}\left[{ }_{\mathrm{AP}} t_{3} t_{1}\right. \text { gammel ]]]] } \\
& \text { Op are you old } \\
& \text { 'How old are you?' } \\
& \text { b. [CP Hvað }{ }_{1} \mathrm{er}_{2}\left[\mathrm{IP}-\mathrm{tu}_{3} t_{2}\left[\mathrm { VP } t _ { 2 } \left[\mathrm{AP} t_{3} t_{1}\right.\right. \text { gammall ]]]] }\right. \\
& \text { what are you old } \\
& \text { 'How old are you?' }
\end{aligned}
$$

Evidence for a null operator comes from the fact that NDQs exhibit the same locality conditions that hold of overt $w h$-movement. For example, the gradable predicate that supports the NDQ can be embedded inside a complement clause, but not a subject, as pointed out by Endresen (1985).

(32a) and (33a) (based on Endresen's examples) form a minimal pair: (32a) is impersonal, with the subject not occupying the canonical subject position, and is acceptable as an NDQ. (33a) has the subject in subject position, and is impossible as an NDQ (though the same string is grammatical as a yes-no question).
a. Tror du det kommer mange?
think you it comes many
'How many do you think will come?'
b. Mente du pinna skulle være lang?
thought you the.stick should be long
'How long did you think the stick should be?'
a. Tror du mange kommer?
think you many come
'Do you think many will come?' (NOT: 'How many do you think will come?')
b. Kor mange tror du kommer?
where many think you come
'How many do you think will come?'

Subjects can be questioned, as indicated in (33b), but it is difficult to subextract from them. Hence the pattern in (32)-(33) is explicable given that NDQs involve the movement of a null operator. This also correctly predicts that NDQs should not escape adjunct islands, as illustrated in (34).

a. Er det viktig at vi har fest fordi har er gammel?

is it important that we have celebration because he is old

'Is it important that we have a celebration because he is old?' (NOT: 'How old is it that his being that old makes it important that we have a celebration?')

b. *Kor gammel er det viktig at vi har fest fordi han er? where old is it important that we have celebration because he is 
The null operator analysis is also compatible with the fact that bare noun phrases, but not noun phrases with overt possessors or determiners, are transparent to $w h$-movement.
a. Trenger du langt tau? need you long rope 'How long a rope do you need?'
b. Kor langt tau trenger du? where long rope need you 'How long a rope do you need?'
a. Trenger du et langt tau? need you a long rope 'Do you need a long rope?' (NOT: 'How long a rope do you need?')
b. *Kor langt et tau trenger du? where long a rope need you

As already noted, the NN NDQ operator has a syntax distinct from the overt degree morpheme $k o r$, as evident from the fact that kor never strands its associated predicate (for completeness we include an example without inversion, since NN has non-inverted $w h$-questions, cf. e.g. Vangsnes to appear).
a. Kor gammel er du?
where old are you
'How old are you?'
b. *Kor er du gammel? where are you old
(Only as: \# 'Where are you old?')
c. *Kor du er gammel? where you are old
(Only as: \# 'Where are you old?')

Following Corver (1990), we can explain facts like (37b-c) by assuming that kor (like English how) is a head which combines directly with a gradable adjective (a Deg $^{0}$ head, presupposing the syntactic analysis to be developed in the next section), and so does not move away from it. The NDQ, like the Icelandic questions with hvað, must therefore contain a phrasal operator in a specifier position, which we will claim occupies the same position as overt measure phrases occupy.

In section 3, we develop a detailed syntactic analysis along these lines, which explains the Salient Measure Restriction (stated in (22) above) in terms of the syntax and semantics of the extended adjectival projection. Before turning to this analysis, however, we must first consider a potentially more direct explantion for this restriction based on the semantics of the null degree operator.

The intuition underlying this approach (as well as the one we develop below) is that whatever principles prevent measure phrases from combining with negative adjectives and adjectives without measurement systems should also prevent the null operator from combining with such adjectives. 
The fact that measure phrases are based on nouns that denote units (see Lehrer 1986) suggests that they presuppopse that the degrees they denote (or quantify over) can be mapped onto a finite set of countable units. We might therefore posit a semantics for null degree questions along the lines of (38).

$\left[\mathrm{Op}_{1} \mathrm{~V} \mathrm{DP} t_{1} \mathrm{~A}\right]$

How many units is the maximal degree $d$ such that DP V $d$-A?

Only adjectives that support measure phrases could support this operator, since the meaning of the operator presupposes the existence of discrete units of measurement. An adjective like young is infelicitous because negative degrees are not countable (Seuren 1978, von Stechow 1984b, Kennedy 2001; see below for more detailed discussion of this point), and an adjective like intelligent is infelicitous because there is no measurement system associated with the intelligence scale (though in specific contexts, such as the IQ test discussed above, one can be imposed, rendering measure phrases and NDQs acceptable).

However, we believe this simple and straightforward account to be incorrect. For one thing, it conflicts with an independently motivated semantics for adjectival constructions which we will elaborate in the next section. For another, it makes incorrect empirical predictions regarding the range of acceptable answers to NDQs.

The predictions can be seen most easily by examining comparatives. The analysis sketched in (38) assigns the interpretation to (39) which is given in (39a), distinct from that in (39b).

Er han mye eldre enn deg?

is he much older than you

'How much older is he than you?'

a. How many units is the maximal degree $d$ such that his age exceeds your age by at least $d$ ?

b. What is the maximal degree $d$ such that his age exceeds your age by at least $d$ ?

The difference gives rise to a subtle difference in prediction regarding the range of felicitous answers to questions like (39). If (40a) is the correct representation, then (41a-b), but not (41c), should be acceptable answers ((41c) should give rise to the reaction, Why are you avoiding my question?). On the other hand, if (40b) is the correct representation, then all of (41a-c) should be felicitous answers.

a. Eight months older.

b. Many months older./A few months older/Not as many months older as I thought.

c. Much older./A little bit older./Not as much older as I thought.

The difference is not simply one of informativity: much older is nearly as informative as many months older. The difference is that (41a-b) are framed explicitly in terms of the information that is requested in (40a): units of age-measurement.

Turning back to the NN question in (39), we find that all of the following are regarded as felicitous answers (though not a simple 'yes' or 'no'). 
a. Åtte måneder eldre. eight months older 'Eight months older'

b. Mange måneder eldre./Noen få måneder eldre./Ikke så mange måneder eldre. many months older/some few months older/not so many months older 'Many months older/A few months older/Not many months older'

c. Mye eldre./Litt eldre./Ikke så mye eldre som eg trodde. much older/little older/not so much older as I thought 'Much older/A little bit older/Not as much older as I thought'

We conclude that the NN NDQ operator cannot be an implicit version of how many units, as in (40a), but must have a more general meaning as an underspecified quantifier over degrees.

$\left[\mathrm{Op}_{1} \mathrm{~V} \mathrm{DP} t_{1} \mathrm{~A}\right]$

What is the maximal degree $d$ such that DP $\mathrm{V} d-\mathrm{A}$ ?

If this is correct, we can maintain our account of the impossibility of NDQs with negative adjectives, given that this operator only quantifies over positive degrees, but it is not obvious from (43) how it is to be restricted to adjectives with salient measurement systems. In fact, the general operator postulated in (43) manifests exactly the kind of quantification argued to be involved in the interpretation of comparative clauses like that in (44) (see von Stechow 1984a, Heim 1985; 2000, Rullmann 1995, among others), clearly not restricted by the Salient Measure Restriction in (22).

a. The pasta is harder in Rome than it is in Tromsø.

b. $\quad . .$. than [CP $\mathrm{Op}_{1}$ the pasta is [ ${ }_{\mathrm{AP}} t_{1} d$-hard in Troms $\varnothing$ ]]

c. ...the maximal $d$ such that pasta is $d$-hard in Troms $\varnothing$

We will argue below that the Salient Measure Restriction should be derived from the semantics of the predicate, rather than the operator.

\section{The syntax of measurement}

The analysis of gradable predicates which we wish to adopt here is one in which degree morphology does not fill an argument position, but rather heads the extended functional projection of the lexical head (Abney 1987, Corver 1990, Grimshaw 1991, Kennedy 1999).

$$
\overbrace{\text { Deg AP }}^{\operatorname{DegP}}
$$

Kennedy (1999) argues in favor of a decompositional semantic analysis of gradable adjectives, in which adjectives do not have degree arguments, but rather denote measure functions-functions from individuals to degrees (type $\langle\mathrm{e}, \mathrm{d}\rangle$ ). For example, the adjective old denotes the function in (46): it takes an object and returns its (positive) degree of age. 


$$
\llbracket \text { old } \rrbracket=\lambda x \text {.the degree to which } x \text { is old }
$$

A consequence of this analysis is that gradable adjectives must combine with some other expression in order to be converted into properties of individuals; this is the function of degree morphology. For example, the unmarked 'positive' form of an adjectival predicate is derived by combining an adjective with a null Deg head pos (possibly overt in some languages; see Sybesma 1999 on Mandarin hen) which has the (simplified) semantics in (47). ${ }^{4}$

$$
\llbracket[\text { Deg } p o s] \rrbracket^{\mathrm{c}}=\lambda \mathrm{g} \lambda \mathrm{x} \cdot \mathrm{g}(\mathrm{x}) \succ \mathrm{d}_{\mathrm{s}(\mathrm{g})(\mathrm{c})}
$$

Here $d_{s(g)(c)}$ represents the 'standard of comparison' for a context of utterance $c$ : the degree that is required to count as having the property measured by $g$ in $c$. Combination of pos with old results in the property in (48), which is true of an object if it has a degree of age that exceeds a contextually determined standard of age.

$$
\lambda x \text {.the degree to which } x \text { is old } \succ \mathrm{d}_{\mathrm{s}(\text { old)(c) }}
$$

Kennedy (1999) shows how this approach extends to comparatives and other complex degree constructions; here we focus on the analysis of measure phrases. If measure phrases denote (or quantify over) degrees, but gradable adjectives do not themselves have degree arguments, then some other element of the structure must provide this position for the measure phrases in expressions like two meters tall, eight months old, five fathoms deep, and so on. We propose that the measure phrase is introduced by a Deg head that we will refer to as Meas, so that an example like eight months old has the structure in (49).

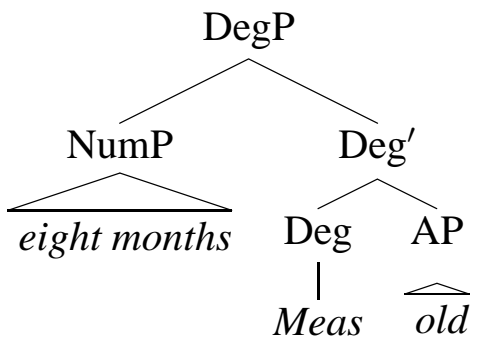

We further suggest that Meas is constrained to combine only with adjectives that denote functions that map their arguments onto measurable degrees. This is stated as a domain (selectional)

\footnotetext{
${ }^{4}$ Most degree morphology will have a semantic type similar to that of pos, and will occupy the $\operatorname{Deg}^{0}$ position. The intensifier very, for example, can be analyzed as a function from adjectives to properties of individuals along the lines of (i), where the context is modified in such a way that just the individuals that 'count as' having the property in question are considered when computing the standard of comparison (Wheeler 1972, Klein 1980, Kennedy and McNally 2005a).

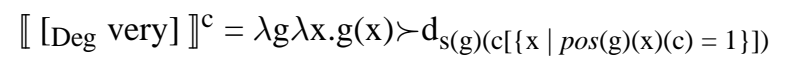

On this view, to be very tall, for example, is to be tall relative to the tall objects in the context. See Kennedy and McNally 2005b for discussion of the semantic and syntactic differences between different types of degree modifiers.
} 
restriction on the adjectival argument of Meas in (50). ${ }^{5}$

$\llbracket[$ Deg Meas $] \rrbracket=\lambda \mathrm{g}: \mathrm{g}$ is a function from objects to measurable degrees $\lambda \mathrm{d} \lambda \mathrm{x} . \mathrm{g}(\mathrm{x}) \succeq \mathrm{d}$

Whether a degree is measurable depends on two factors. The first is whether the scale that it comes from is associated with a measurement system in the first place: AGE is; FATIGUE is not, thus Meas is compatible with the adjective old (which denotes a function from objects to degrees of age) but not with the adjective tired (which denotes a function from objects to degrees of fatigue). Some adjectives may also permit contextual accomodation of a measurment system (as we saw in section 1.3 for intelligent in the context of an IQ test); the semantics of Meas requires that they must take on this kind of meaning whenever they project a degree argument.

The second factor is a purely structural one: whether the degree is bounded or unbounded. This distinction is relevant to the characterization of adjectival polarity. According to Seuren (1978), von Stechow (1984b) and Kennedy (2001), an antonymous pair like old and young both measure objects according to the same general scale (AGE in this case), but differ in that old maps its arguments onto bounded, measurable 'positive' degrees (degrees that originate at the zero point of a scale), while young maps its arguments onto unbounded, unmeasurable 'negative' degrees (degrees that range from some value to the upper reaches of the scale).

The end result is that the set of adjectives that can combine with Meas to project a degree argument is a fairly restricted one: adjectives that map their arguments onto bounded intervals of scales associated with a measurement system. This set includes the positive dimensional adjectives in the leftmost column of the table in (12), and, as we will show below, comparative forms of both positive and negative dimensional adjectives. This is the set of adjectives that permit overt measure phrases in Northern Norwegian, and as we saw in section 1.3, the set of adjectives that permit NDQs. Below we demonstrate how our analysis derives this correlation.

We begin by assuming a very general semantics for questions formed using the null NN degree quantifier (and its overt counterpart in Icelandic), along the lines of (51).

$\left[\mathrm{Op}_{1} \mathrm{~V}\right.$ DP [DegP $t_{1}$ Meas A]]

What is the maximal degree $d$ such that DP $\mathrm{V} d$-A?

The operator in (51) does not quantify over units of measurement, as was the case with (38), our first attempt at deriving the Salient Measure Restriction, and so does not run into the problem of incorrect expectations about answers that we documented above. Instead, the operator in (51) simply asks for a (maximal) degree, and so may in principle target any degree variable.

As observed above, this analysis of the null degree quantifier runs into problems if all gradable adjectives introduce a degree argument, as is standardly assumed (i.e., under standard assumptions the semantic type of a gradable adjective is $\langle d,\langle e, t\rangle\rangle)$, since it would be impossible to ensure that the operator in (51) combines only with adjectives that are associated with measurement systems. Under the analysis proposed here, however, the degree argument is introduced by Meas rather

\footnotetext{
${ }^{5}$ Note that the semantics of Meas is distinct from that of pos, and as Deg heads, the two morphemes are in complementary distribution. This explains the fact that a predication involving a measure phrase generates no entailments to the positive form: a 10 month old baby need not be an old baby.
} 
than by a gradable adjective (which is type $\langle e, d\rangle$ ). Since the null degree operator originates in this position (it quantifies over the degree variable introduced by Meas, the same variable that is restricted by an overt measure phrase), it follows that only those adjectives that can independently combine with Meas will form null degree questions.

For example, in the case of (52a-c), only (52a) is well-formed, since only gammel 'old' has a meaning that permits combination with Meas and projection of a position for the operator. ${ }^{6}$
a. $\mathrm{Op}_{1}$ er du [DegP $t_{1}$ Meas [AP gammel]]?
Op are you old
'How old are you?'
b. ${ }^{*} \mathrm{Op}_{1}$ er du [DegP $t_{1}$ Meas [AP ung]]?
Op are you young
'How old are you?'
c. $* \mathrm{Op}_{1}$ er du [DegP $t_{1}$ Meas [AP trøtt]]?
Op are you tired
'How old are you?'

Neither ung 'young' nor trøtt 'tired' map their arguments onto measurable degrees, so combination with Meas as in (52b-c) is precluded, rendering a degree question parse impossible. The Salient Measure Restriction on Northern Norwegian degree questions thus follows from the selectional restrictions on Meas.

Turning now to comparatives, we saw earlier that comparative forms of both negative adjectives permit measure phrases and give rise to NDQs even when the non-comparative forms (of the negative adjectives) do not.
a. Han Julian er åtte måneder yngre enn han Sam.
he Julian is eight months younger than he Sam
'Julian is eight months younger than Sam'
b. Er han mye yngre enn deg?
is he much younger than you
'How much younger is he than you?'

One potential (but, we will argue, wrong) explanation of this fact would be that the comparative degree morphology is like Meas in that it introduces a degree argument, namely the 'differential degree' that measures the distance between the compared objects (Hellan 1981, von Stechow 1984a, Kennedy 2001, Schwarzschild and Wilkinson 2002, Schwarzschild to appear):

\footnotetext{
${ }^{6} \mathrm{~A}$ relevant question is how the NDQ operator escapes the DegP, given that measure expressions are not ordinarily extractable:

(i) *Tretti år ${ }_{1}$ er han [DegP $t_{1}$ Meas [AP gammel]]

thirty years is he old

We will assume that this is because measure phrases do not have independent reference, and so are invisible to topicalization and scrambling operations. The NDQ operator, in contrast, has $w h$-features and so is attracted by the interrogative $\mathrm{C}$.
} 
a. $\llbracket$-er/more $\rrbracket=\lambda \mathrm{g} \lambda \mathrm{d}_{1} \lambda \mathrm{d}_{2} \lambda \mathrm{x} \cdot \mathrm{g}(\mathrm{x})-\mathrm{d}_{1}=\mathrm{d}_{2}$

b. $\quad \llbracket$ DegP two meters longer than $\mathrm{Y} \rrbracket=\lambda \mathrm{x}$. the degree to which $\mathrm{x}$ is long minus the degree to which $\mathrm{Y}$ is long $=$ two meters

But if our claims about the semantics of Meas and the NN NDQ operator are correct, then (54a) can't be the right analysis of comparatives; it would wrongly predict that the null degree operator could combine with any comparative, regardless of the semantic properties of the adjectival base. That this is incorrect is demonstrated in (55).

a. Er han mye trøttere enn deg?

is he much tireder than you

'Is he much more tired than you?'/*'How much more tired is he than you?'

b. $\quad$ E er (*fem timer) trøttere enn deg.

I am five hours tireder than you

'I am (*five hours) more tired than you'

(55) shows that adjectives that are not associated with measurement systems do not have NDQ readings in comparatives; but if we adopt the analysis of comparatives described above, we run into the same problem we had with the standard analysis of gradable adjectives: we provide a predicate (the comparative form) a degree argument when it shouldn't have one, i.e., even when the adjectival base does not use a scale that supports measurement.

A second problem for this analysis comes from the fact that mye 'much' is crucial to deriving the DQ interpetation of a comparative: without it, comparatives have only YN interpretations, regardless of polarity:
Er han (mye) eldre/yngre enn deg?
is he (much) older/younger than you
'Is he (much) older/younger than you?'
'How much older/younger than you is he?' *(mye)

If comparative morphology introduced a degree argument, there would be no syntactic or semantic distinction between it and Meas (in the relevant respects), and no obvious reason to require the presence of mye 'much' to get the DQ interpretation.

We can account for this data if we adopt the analysis of comparatives proposed in Kennedy and McNally 2005a, in which comparatives are not true degree morphemes, but rather expressions that map adjective meanings to new adjective meanings (i.e., adjectival modifiers; cf. Neeleman et al. 2004). Kennedy and McNally propose that comparative morphology takes a gradable adjective meaning (a from individuals to degrees) and returns a new one that is just like the old one except that it uses a scale whose zero point is the degree denoted by the than-clause.

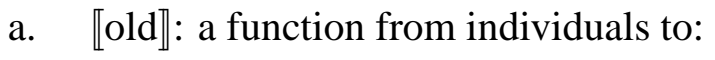

AGE: 0

b. [older than Sam $\rrbracket$ : a function from individuals to the square-bracketed part of:

AGE: 0 - - - - Sam's age - - - - [o 
Since the comparative+adjective constituent denotes a function from individuals to degrees, it must combine with a Deg head to derive a property of individuals. A very similar proposal has been made on independent syntactic grounds by Corver (1997a;b), who argues that comparative morphology fills a functional head between AP and DegP:

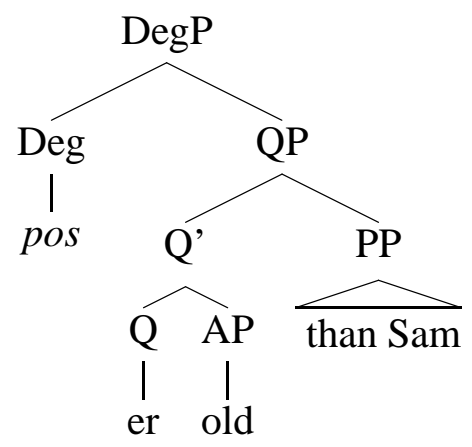

In Kennedy and McNally's analysis, simple comparatives involve combination with pos, and are assigned a 'minimum standard' interpretation: the structure in (58) denotes a property that is true of an object if it has a non-zero degree of 'older-than-Sam-ness'; i.e., if its degree of age exceeds Sam's (maximal) degree of age.

Here we propose that differential comparatives involve combination with Meas, as in (59).

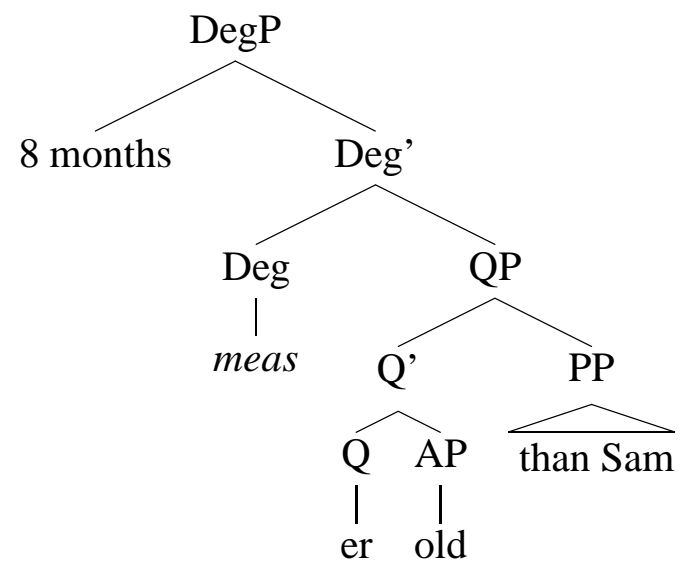

What is crucial for our proposal is that the semantics of comparatives will entail that both positive and negative comparatives map their arguments onto bounded and measurable degrees, since both involve measurement from a derived 'zero point': the degree denoted by the compoarative clause. This is illustrated for the case of older/younger than Sam in (60)-(61).

a. [DegP 8 months older than Sam]

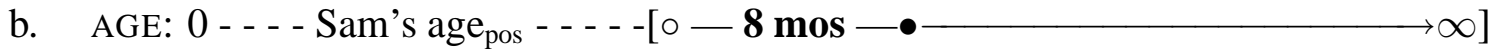

a. [DegP 8 months younger than Sam]

b. AGE: $\left[0 \longleftarrow-18\right.$ mos - o]- - - Sam's age neg $^{---~} \rightarrow \infty$ 
It follows that both older than Sam and younger than Sam can combine with Meas and introduce a degree argument for the NN null degree operator to bind. In contrast, comparatives formed out of adjectives like tired still make use of scales without measurement systems. Combination with Meas is therefore impossible, and no degree argument is projected.

Finally, this analysis also provides a basis for explaining the fact mye 'much' is required to obtain a DQ interpretation in NN, since it posits a syntactic distinction between comparatives and lexical adjectives: as illustrated by (62a-b), the former contain a layer of functional structure between meas and A; the latter do not.

a.

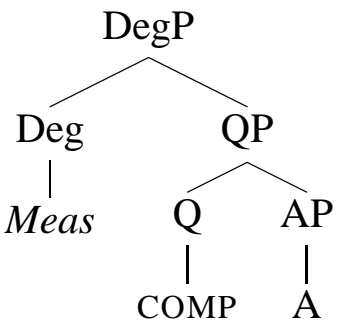

b. $\quad$ DegP

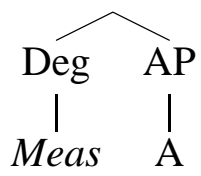

The exact nature of the constraint that forces the appearance of mye remains a question for future work. For now, we hypothesize that the Meas head, like the overt word kor, its English counterpart how, and modifiers like very, combines with AP, not QP (cf. *very taller, *how taller, etc.). The word mye 'much' is an A (or a category-changing morpheme; cf. very much, how much) inserted to ensure that the syntactic selectional requirements of Meas are satisfied:

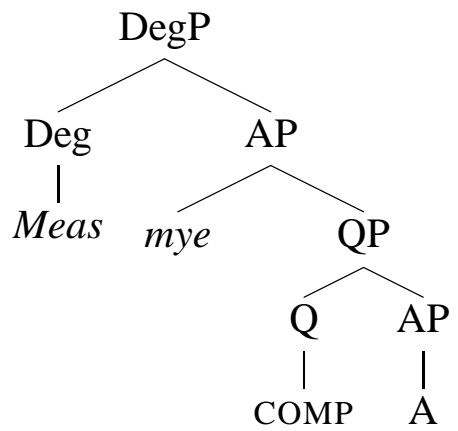

\section{Conclusions}

This paper has proposed that Null Degree Questions in Northern Norwegian are derived by moving a phonologically null operator from a degree argument position inside a gradable predicate - the same position occupied by a measure phrase - to SpecCP. We have claimed that the restriction of such questions to predicates that are associated with salient measurement scales (the Salient Measure Restriction) follows from a more general hypothesis about the projection of degree arguments of gradable predicates. Such arguments are not specified in the lexical entry of the predicate, as is standardly assumed, but are rather introduced by functional morphology in the extended projection of the adjective (our Meas head). Whether a degree argument can be projected or not depends on the semantic properties of the lexical (adjectival) head: whether the scale it is assocated with comes 
with a measurement system (or whether one can be contextually accommodated), and whether the degrees onto which it maps its argument are measurable (the positive vs. negative). A consequence of this analysis is that gradable adjectives must be analyzed as measure functions (type $\langle e, d\rangle$ ), rather than as relations between individuals and degrees (type $\langle d,\langle e, t\rangle\rangle$ ), and that the lexical adjective must project extended functional structure.

\section{References}

Abney, Steven P. 1987. The English noun phrase in its sentential aspect. Doctoral Dissertation, Massachusetts Institute of Technology, Cambridge, Mass.

Bull, Tove. 1987. Eit nordlig syntaktisk drag i norsk. Maal og Minne 1-2/3-4:137-141.

Corver, Norbert. 1990. The syntax of left branch extractions. Doctoral Dissertation, Tilburg University.

Corver, Norbert. 1997a. The internal syntax of the Dutch adjectival projection. Natural Language and Linguistic Theory 15:289-368.

Corver, Norbert. 1997b. Much-support as a last resort. Linguistic Inquiry 28:119-164.

Endresen, Øyalf. 1985. E a mang, klokka? Maal og Minne 3-4:249-262.

Grimshaw, Jane. 1991. Extended projection. Unpublished ms., Brandeis University.

Heim, Irene. 1985. Notes on comparatives and related matters. Ms., University of Texas, Austin, TX.

Heim, Irene. 2000. Degree operators and scope. In Semantics and Linguistic Theory 10, ed. Brendan Jackson and Tanya Matthews, 40-64. Ithaca, NY: CLC Publications.

Hellan, Lars. 1981. Towards an integrated analysis of comparatives. Tübingen: Narr.

Kennedy, Christopher. 1999. Projecting the adjective: The syntax and semantics of gradability and comparison. New York: Garland. (1997 UCSC Ph.D thesis).

Kennedy, Christopher. 2001. Polar opposition and the ontology of 'degrees'. Linguistics and Philosophy 24:33-70.

Kennedy, Christopher. 2002. Comparative deletion and optimality in syntax. Natural Language \& Linguistic Theory 20.3:553-621.

Kennedy, Christopher, and Louise McNally. 2005a. Scale structure and the semantic typology of gradable predicates. Language 81:345-381.

Kennedy, Christopher, and Louise McNally. 2005b. The syntax and semantics of multiple degree modification in English. Paper presented at the 12th International Conference on HPSG, August 23, 2004, Lisbon.

Klein, Ewan. 1980. A semantics for positive and comparative adjectives. Linguistics and Philosophy 4:1-45.

Lehrer, Adrienne. 1986. English classifier constructions. Lingua 68:109-148.

Midtgård, Tone. 1995. Yes/no interrogatives as wh-questions: The syntax and intonation of a norwegian grammatical construction. In Papers from the XVth Scandinavian Conference of Linguis- 
tics, ed. Inger Moen, Hanne Gram Simonsen, and Helge Lødrup, 374-380. Oslo: Department of Linguistics, University of Oslo.

Neeleman, Ad, Hans Van de Koot, and Jenny Doetjes. 2004. Degree expressions. The Linguistic Review 21:1-66.

Rivero, María-Luisa. 1981. Wh-movement in comparatives in spanish. In Linguistic Symposium on Romance Languages 9, ed. William Cressey and Donna Jo Napoli, 177-196. Washington, DC: Georgetown University Press.

Rullmann, Hotze. 1995. Maximality in the semantics of wh-constructions. Doctoral Dissertation, University of Massachusetts, Amherst, MA.

Schwarzschild, Roger. to appear. Measure phrases as modifiers of adjectives. Recherches Linguistiques de Vincennes.

Schwarzschild, Roger, and Karina Wilkinson. 2002. Quantifiers in comparatives: A semantics of degree based on intervals. Natural Language Semantics 10:1-41.

Seuren, Pieter A.M. 1978. The structure and selection of positive and negative gradable adjectives. In Papers from the Parasession on the Lexicon, Chicago Linguistics Society, ed. W.M. Jacobsen Farkas, Donka and K.W. Todrys, 336-346. Chicago: Chicago Linguistic Society.

von Stechow, Arnim. 1984a. Comparing semantic theories of comparison. Journal of Semantics $3: 1-77$.

von Stechow, Arnim. 1984b. My reply to Cresswell's, Hellan's, Hoeksema's and Seuren's comments. Journal of Semantics 3:183-199.

Sybesma, Rynt. 1999. The mandarin VP. Boston: Kluwer.

Vangsnes, Øystein Alexander. to appear. Microparameters for Norwegian wh-grammars. Linguistic Variation Yearbook 5.

Wheeler, Samuel. 1972. Attributives and their modifiers. Nô̂s 6:310-334.

Svenonius

Department of Linguistics, CASTL

Faculty of Humanities

University of Troms $\varnothing$

N-9037 Troms $\varnothing$ NORWAY

peter.svenonius@hum.uit.no

Kennedy

Department of Linguistics

University of Chicago

1010 E. 59th St.

Chicago, IL 60637 USA

ck@uchicago.edu 